\section{ECONOMICS}

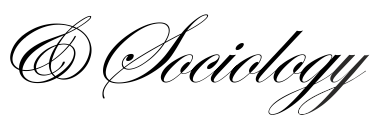

\title{
MULTIDIMENSIONAL INEQUALITY IN THE EUROPEAN UNION. THE JOINT DISTRIBUTION OF HOUSEHOLD INCOME, WEALTH, AND CONSUMPTION ${ }^{1}$
}

\begin{abstract}
Marcin Wroński
Collegium of World Economy,

Warsaw School of Economics

Warsaw, Poland

Email:mwronsk@,sgh.waw.pl
\end{abstract}

Received: December, 2020

1st Revision: April, 2021

Accepted: August, 2021

DOI: $10.14254 / 2071-$

789X.2021/14-3/11

\begin{abstract}
We use a novel cross-country data set to measure multidimensional inequality of income, wealth, and consumption in $21 \mathrm{EU}$ countries. We investigate the correlation between the positions of the household in their distributions. We use the bootstrap method to assess the statistical significance of cross-country differences. We find that the correlation between the position of the household in considered distributions varies significantly across countries. Homeownership, median income, and level of unidimensional inequalities are correlated with the strength of the link between distributions. Multidimensional analysis of inequality changes the picture emerging from the unidimensional inequality analysis. Wealth inequality is a crucial contributor to multidimensional inequality. Cross-country differences in multidimensional inequality in the European Union are rather mild.
\end{abstract}

JEL Classification: D31, D63

Keywords: income distribution, wealth distribution, consumption distribution, multidimensional inequality, European Union

\section{Introduction}

Wellbeing is a multidimensional concept (Stiglitz et al., 2009; OECD, 2020). However, researchers studying social and economic inequality usually analyze inequality only in one of the dimensions. Although there is rich and growing literature on income inequality, wealth inequality, and consumption inequality, those dimensions are in most cases treated separately. Studies of their joint distribution are rare and mostly constrained to a single country level. The availability of joined high-quality data on income, wealth, and consumption, especially at the cross-country level is low, which strongly limits the possibilities to analyze multidimensional inequalities.

In this paper, we use a novel cross-country dataset to analyze the multidimensional inequality of income, wealth, and consumption to investigate the correlation between the positions of the household in their distributions in 21 member states of the European Union. We calculate the multidimensional inequality index developed by Araar (2009) to measure

\footnotetext{
${ }^{1}$ This paper uses data from the Eurosystem Household Finance and Consumtpion Survey. This study has been funded by SGH Warsaw School of Economics under contract KGS/S20/17/2020.
} 
multidimensional inequality. We apply the bootstrap method to analyze the significance of cross-country differences of multidimensional inequality and correlations and use rigorous criteria to rank countries in those areas.

The paper is organized as follows. The first section reviews the literature on multidimensional inequality. The next section presents the data and methods used in the paper. Empirical results are discussed in the third section. Section four analyzes determinants of the correlation between the position of the household in the distribution of income, wealth, and consumption. The last section concludes, discusses the limitations of our research, and indicates areas for future research.

\section{Literature review}

Economic inequality has been investigated by many great economists, among them: $\mathrm{F}$. Quesnay, A. Smith, A. Turgot, V. Pareto, A.B. Atkinson, A. Sen, J. Stiglitz, and P. Krugman. In the 1990s interest in economic inequality decreased, while more attention has been dedicated to the issue of poverty (Reid-Henry, 2015). Today after the Great Financial Crisis and the publication of "Capital in the Twenty-First Century" (Piketty, 2015) the issue of economic inequality is back in the mainstream of economics and political debate (Hirschman, 2016).

Research on economic inequality is usually focused only on single dimension metrics like income or wealth. Although, knowledge of income or wealth inequality is useful and important an unidimensional analysis of inequality is not sufficient to fully understand the scale of inequalities in the society (Sen, 1997). On the one hand, households who are privileged in one of the dimensions probably also have relatively good positions in other dimensions. On the other hand, however, the correlation between dimensions is not perfect. For example, many older households have accumulated significant wealth, but at the same time, their incomes and consumption are often lower than in the case of many prime workingage households.

During the last four decades, economists and econometricians developed many tools to measure multidimensional inequality. Multidimensional versions of many important unidimensional inequality indices have been formulated. Kolm (1977), Atkinson and Bourguignon (1982), and Maasoumi (1986) pioneered in the area of the multidimensional inequality measurement, while Fluckiger \& Silber (1994), Tsui (1995, 1999), Koshevoy \& Mosler (1997), List (1999), Gajdos \& Weymark (2005), Araar (2009), Banerjee (2010), and Bosmans et al. (2015) are most important recent contributions. Presentations of all methods of the multidimensional inequality measurement and discussions of their strengths and flaws are out of the scope of this paper. Aaberge and Brandolini (2015) provide an excellent review of the literature on multidimensional inequality measurement. Therefore we prefer to review the most important empirical applications of multidimensional inequality measurement than to discuss its methodology.

Data availability is the most important factor constraining multidimensional inequality analysis, especially at the cross-country level. Although many surveys on household income, consumption, and wealth exist the strong majority of them are concentrated only on one of the dimensions. For example, the leading European household survey - European Union Statistics on Income and Living Conditions (EU SILC) provides rich information on household incomes and relatively good data on household consumption, but only strictly limited information on household wealth. European Household Budget Survey provides the best data on household expenditure on goods and services but ignores other dimensions.

Because of data constraints, growing literature on multidimensional inequality mostly covers only single countries. Wellbeing dimensions covered in the research on 
multidimensional inequality vary among authors. Justino et al. (2004) study multidimensional inequality of household income, health, education, and political participation in Brazil. Lugo (2007) analyzes multidimensional inequality in the areas of household income, life expectancy, and years of education in Argentina. Kennickel (2009) studies the joint distribution of income and wealth in the US. Decancq \& Lugo (2012) investigate multidimensional inequality of household expenditure, health, schooling, and housing quality in Russia. Clementi and Gianmoena (2017) examine the joint distribution of income and wealth in Italy. Steiner \& Zhu (2021) study the top-corrected joint distribution of income and wealth in Germany. Van Phan and O'Brien (2019) scrutinize multidimensional wellbeing inequality in Vietnam using data on assets participation, education, health, and housing. Multidimensional inequality in Vietnam has been also studied by Bui \& Erreygers (2020), who analyze the inequality of household consumption, education, health, and housing. Khan et al. (2021) investigate multidimensional inequality of household expenditure, education, health, and housing across different occupations in Pakistan. Jung et al. (2014) in their research on multidimensional inequality in South Korea cover ten different dimensions of inequality - from household incomes and employment, through leisure and work-family reconciliation to social security and social capital. Methods of multidimensional inequality analysis have been also used in the study of racial (Rohde \& Guest, 2012) and gender (Permanyer, 2010) disparities.

We decide to investigate the multidimensional inequality of household income, consumption, and wealth. In our view chosen dimensions form the economic foundation of household well-being. The joint analysis of income, consumption, and wealth increases our knowledge of household material well-being and economic vulnerability. Moreover, are dataset is a good source of information on those three dimensions Literature indicates that the study of multidimensional inequalities in those dimensions provides additional insight into economic inequality in comparison with single dimensions studies.

Ruiz (2018) examines the inequality of joined distribution of income, wealth, and consumption in France. He concludes that multidimensional analysis reveals differences that cannot be found using income data alone. The structure of consumption and wealth of households belonging to the same decile of income distributions differs significantly. Fisher et al. (2018) analyze the multidimensional inequality of income, consumption, and wealth in the US using data from 1989-2016 Surveys of Consumer Finances (SCF). The SCF is a leading survey of household wealth in the US. It has many similarities with our data source the Household Finance and Consumption Survey run by the European Central Bank. Authors find that in the studied period multidimensional inequality increased much faster than unidimensional inequality. ONS (2020) investigates the joint distribution of income, spending, and wealth in the UK to compare spending, income, and value of liquid assets, which might be used to sustain a period of "overspend". ONS finds that in the case of nearly $40 \%$ of households levels of spending are higher than levels of income. About half of these households can sustain overconsumption for less than a year selling their liquid assets, while more than a quarter can sustain overconsumption for more than six years. Age is the crucial determinant of the household position in the joined distribution.

Only a few authors study multidimensional inequality in a cross-country setting. Jäntti et al. (2015) investigate the joint distribution of income and wealth in five OECD countries using results of different wealth surveys harmonized in the Luxembourg Wealth Survey (LWS) data set. They find that wealth inequality is a crucial driver of multidimensional inequality. According to their results correlation between both distributions varies among countries. Authors note that their results may be partly driven by methodological differences in country surveys. In this paper, we use one cross-country survey as a data source, which eliminates this constraint. Brandolini (2009) investigate the multidimensional inequality of 
income and health using European Community Household Panel data in four advanced European economies. He concludes that the analysis of multidimensional inequalities modifies the picture drawn from income data alone. While income inequality in Germany is lowest among countries in the sample, the distribution of wellbeing is most unequal. Some authors combine microdata with macrodata to mitigate data constraints. For example, Decancq (2016) measures multidimensional inequality in OECD countries using the distribution-sensitive Better Life Index, while Parente (2019) combines macrodata and microdata from EU-SILC to calculate the Inequality-adjusted Human DevelopmentIndex across European regions.

\section{Data and method}

We use a dataset from the third wave of Household Finance and Consumption Survey (HFCS). The HFCS is coordinated by the European Central Bank and conducted in a decentralized way by national central banks and statistical agencies. The harmonized core set of questions is used in all countries The HFCS covers all Eurozone countries as well as Croatia, Hungary, and Poland. Microdata for Spain is not yet available for researchers, which limits our sample to 21 countries. HFCN (2020a) reviews the main outcomes of the survey, while HFCN (2020b) provides rich information on survey methodology. The survey has been conducted in all countries in 2016 or 2017 . Microdata from the third wave of the HFCS is available for researchers since March 2020.

Net wealth, household income, and consumption of goods and services are our variables of interest. Net wealth equals the value of household assets minus the value of household liabilities. Following the OECD Guidelines for Micro Statistics on Household Wealth, the net wealth measure excludes the value of public pension plans because those savings cannot be freely used by households. Moreover, measurement of the value of savings in public pension plans requires strong actuarial assumptions (OECD, 2013).

The household income is given as gross household income including regular social transfers as well as regular transfers from relatives. It is the broadest income measure available in the HFCS dataset. Unfortunately, the HFCS dataset does not contain measures of household income after taxes (net income) and we do not have enough data to calculate the net income of the household. The usage of gross household income instead of net household income inflates the level of income inequality in comparison with EU-SILC data.

We measure household consumption using the amount spent on consumer goods and services. Such an approach excludes spending on durable goods. The exclusion of durable goods is common in the study of household consumption because consumption of durable goods is hard to measure. Even if we may monitor the spending on durable goods at the time of purchase, such goods are consumed over a medium- to long period. Among households, who spend less than their income the mean share of spending on goods and services in income is $37.6 \%$ percent. The measure of consumption used in this paper is less than perfect, but it is the best our dataset has. It would be beneficial to replicate the research in the future using better data on consumption, but as far as we know higher quality data on consumption joined with the data of income and wealth of the same quality as in the HFCS are not available.

Because wealth is usually not equalized we also do not equalize income and consumption measures. Equalizing only some dimensions will artificially decrease their contribution to multidimensional inequality measures. Moreover, results based on equalized data may be highly dependent on the choice of the equalization method.

HFCS uses multiple imputations to solve the problem of missing data. Multiple imputation routines are discussed in detail in HFCN (2020b). In our calculations we use the values averaged over five imputations. Such an approach follows Rubin's rule (Rubin, 1987). 
Because richer households are less willing to participate in wealth surveys (Kennickel, 2019; Wroński, 2019) HFCS, similarly to Survey on Consumer Finances (SCF) oversamples wealthy households. Oversampling strategies are decided on the national level. Although oversampling increases the coverage of wealthy households, research based on national rich lists indicate that HFCS still misses the top of the wealth distribution both in Western Europe (Bach et al., 2019) as well as in Central and Eastern Europe (Brzeziński et al., 2020). In both regions, top-corrected measures of wealth inequality are significantly higher than measures based only on HFCS data. In all calculations, we use survey weights attached to households by survey organizers.

Table 1 provides information on sample size and crucial descriptive statistics. The net sample size varies between 1004 in Malta and 13685 in France. The sample sizes are more than adequate for our purpose. The oversampling ratio of the top deciles varies between $-15 \%$ in Austria and $158 \%$ in France. The median value of household income, wealth, and consumption differ significantly among countries. HFCN (2020c) presents detailed statistical tables on the distribution of household assets and liabilities as well as household characteristics.

Table 1. Descriptive statistics

\begin{tabular}{lccccccc}
\hline Country & $\begin{array}{c}\text { Sample } \\
\text { size }\end{array}$ & $\begin{array}{c}\text { Median } \\
\text { income } \\
\text { thou.€ }\end{array}$ & $\begin{array}{c}\text { Median } \\
\text { net } \\
\text { wealth } \\
\text { thou.€ }\end{array}$ & $\begin{array}{c}\text { Median } \\
\text { consumption } \\
\text { thou. } €\end{array}$ & $\begin{array}{c}\text { \% } \\
\text { owning } \\
\text { main } \\
\text { residence }\end{array}$ & $\begin{array}{c}\text { \% 65 } \\
\text { and } \\
\text { over }\end{array}$ & $\begin{array}{c}\text { Oversampling } \\
\text { rate of the top } \\
\text { decile }\end{array}$ \\
\hline Austria & 3072 & 41.4 & 85.2 & 12.0 & $45.9 \%$ & $29.4 \%$ & $-15 \%$ \\
\hline Belgium & 2329 & 44.0 & 210.0 & 14.4 & $69.3 \%$ & $34.7 \%$ & $46 \%$ \\
\hline Cyprus & 1303 & 26.0 & 207.1 & 12.0 & $68.2 \%$ & $21.1 \%$ & $58 \%$ \\
\hline Germany & 4942 & 40.2 & 70.9 & 8.4 & $54.9 \%$ & $36.7 \%$ & $140 \%$ \\
\hline Estonia & 2672 & 16.4 & 48.0 & 7.6 & $75.3 \%$ & $26.4 \%$ & $35 \%$ \\
\hline Finland & 10210 & 40.8 & 107.2 & 16.7 & $66.3 \%$ & $25.7 \%$ & $83 \%$ \\
\hline France & 13685 & 32.6 & 117.6 & 10.6 & $57.9 \%$ & $28.6 \%$ & $158 \%$ \\
\hline Greece & 3007 & 19.1 & 60.7 & 9.6 & $72.0 \%$ & $31.6 \%$ & $-8 \%$ \\
\hline Croatia & 1357 & 8.6 & 63.0 & 7.0 & $85.3 \%$ & $30.9 \%$ & $16 \%$ \\
\hline Hungary & 5968 & 11.1 & 35.9 & 5.1 & $84.0 \%$ & $35.4 \%$ & $69 \%$ \\
\hline Ireland & 4793 & 48.0 & 190.0 & 16.8 & $69.5 \%$ & $29.8 \%$ & $72 \%$ \\
\hline Italy & 7420 & 24.6 & 132.3 & 12.7 & $68.5 \%$ & $42.9 \%$ & $5 \%$ \\
\hline Lithuania & 1664 & 7.5 & 47.4 & 5.3 & $93.2 \%$ & $28.0 \%$ & $33 \%$ \\
\hline Luxembourg & 1616 & 71.1 & 500.3 & 23.3 & $69.0 \%$ & $17.3 \%$ & $45 \%$ \\
\hline Latvia & 1249 & 10.2 & 20.3 & 6.0 & $72.7 \%$ & $31.8 \%$ & $69 \%$ \\
\hline Malta & 1004 & 25.4 & 236.0 & 9.0 & $81.4 \%$ & $34.7 \%$ & $-6 \%$ \\
\hline Netherlands & 2556 & 44.8 & 71.1 & 5.7 & $57.5 \%$ & $38.8 \%$ & $26 \%$ \\
\hline Poland & 5858 & 13.6 & 61.6 & 7.2 & $79.3 \%$ & $29.1 \%$ & $-5 \%$ \\
\hline Portugal & 5924 & 17.7 & 75.5 & 8.4 & $74.5 \%$ & $31.2 \%$ & $81 \%$ \\
\hline Slovenia & 2014 & 16.6 & 94.0 & 9.6 & $76.3 \%$ & $27.3 \%$ & $-2 \%$ \\
\hline Slovakia & 2179 & 16.3 & 70.7 & 8.4 & $88.0 \%$ & $33.7 \%$ & $-17 \%$ \\
\hline Source & 2176 & & & \\
\hline
\end{tabular}

Source: own calculation using HFCS data, HFCN (2019b), HFCN (2020)

To measure the correlation between the position of the household in the income distribution and the position of a given household in the wealth distribution we use Spearman's rank correlation coefficient and Kendall's Tau rank correlation coefficient. Because both measures of correlations provide a nearly identical ranking of countries we only 
present and discuss Spearman's rank correlation coefficient. Values of Kendall's Tau are available upon request.

We use the multidimensional inequality index formulated by Araar (2009). This formulation obeys the anonymity principle, population principle, and Pigou-Dalton transfer principle. It is built on two fundamental axioms: Uniform Majorization Principle (Kolm, 1977) and Correlation Increasing Majorization (Tsui, 1999). According to the first axiom, multidimensional inequality grows if inequality of one of the dimensions increases. According to the second axiom higher correlation between components implies the rise in multidimensional inequality. Araar's (2009) multidimensional inequality index for K dimensions takes the following form:

$$
I=\sum_{i=1}^{k} \varphi_{k}\left[\alpha_{k} I_{K}+\left(1-\alpha_{k}\right) C_{k}\right]
$$

where $\varphi_{k}$ is the weight attributed to the dimension $\mathrm{k}, \mathrm{I}_{\mathrm{k}}$, and $\mathrm{C}_{\mathrm{k}}$ are respectively the Gini index and concentration indices of the dimension $\mathrm{k}$. The parameter $\alpha_{k}$ controls the sensitivity to the correlation between dimensions. We attribute the same weight to income, wealth, and consumption. Araar's (2009) multidimensional inequality index, similar to the Gini Index (Lerman \& Yitzhaki 1985; Araar, 2006; Cowell, 2011) can be decomposed to show the contribution of each dimension.

Many authors studying inequality report only point estimates of inequality indices. Although point estimates provide a useful insight into inequality, they are not enough to compare cross-country inequalities. Because inequality is usually measured using survey data cross country differences may reflect not only differences in the level of inequality but also sampling variance. To assess the statistical significance of the difference in measures used in this paper we follow Sosa Escudero \& Gasparini (2000) and apply the bootstrap method (Biewen, 2002; Chernick, 2008). We use 1000 replications and calculate confidence intervals using the percentile method. The point estimate is the mean of the empirical distribution of bootstrapped coefficients. 0.025 and 0.975 quantiles of the empirical distribution of bootstrapped coefficients are respectively the lower and the upper limit of 95\% Confidence Interval. We assess the difference between estimates of multidimensional inequality and Spearman's correlation as significant if their 95\% confidence intervals do not intersect.

One of our goals is to provide a ranking of countries. Because our sample includes 21 countries metrics calculated for each country are compared with metrics calculated for 20 other countries. We interpret the level of multidimensional inequality/correlation in a given country as very high if it is significantly higher than in the case of more than 15 countries. We assess the level as high if it is significantly higher than in the case of more than 10 countries. We evaluate the level as low if it is significantly lower than in the case of more than 10 countries. We assess the level as very low if it is significantly lower than in the case of more than 15 countries. It shall be noted that our ranking is relative. We compare countries with each other, but we do not assess the absolute degree of inequality. Assessment of the absolute value, without comparisons with other countries, would be fully arbitrary.

\section{Results}

Table 2 present the correlation between the position of the household in all distributions. In all cases, the hypothesis of the null correlation is rejected. A higher position in one of the distributions is connected with a higher position in all distributions. The strength of the correlation varies significantly among countries. On average, the correlation between 
the position of the household in the income distribution and the position of the household in the consumption distribution is highest. The correlation between the position of the household in the wealth distribution and the position of the household in the consumption distribution is lowest. However, it should be noted that different country pattern exists. For example, in the Netherlands correlation is higher in the case of income and wealth than in the case of income and consumption. In Lithuania correlation is higher in the case of wealth and consumption than in the case of income and wealth.

Table 2. Correlation between the positions of the household in unidimensional distributions

\begin{tabular}{|c|c|c|c|}
\hline Country & $\begin{array}{c}\text { Spearman's rank } \\
\text { correlation Income - } \\
\text { wealth }\end{array}$ & $\begin{array}{c}\text { Spearman's rank } \\
\text { correlation Income - } \\
\text { consumption }\end{array}$ & $\begin{array}{c}\text { Spearman's rank } \\
\text { correlation Wealth - } \\
\text { consumption }\end{array}$ \\
\hline Austria & $\begin{array}{c}0.5327 \\
(0.0140) \\
\end{array}$ & $\begin{array}{c}0.6566 \\
(0.0110) \\
\end{array}$ & $\begin{array}{c}0.4329 \\
(0.0155) \\
\end{array}$ \\
\hline Belgium & $\begin{array}{c}0.5039 \\
(0.0163) \\
\end{array}$ & $\begin{array}{c}0.5986 \\
(0.0144)\end{array}$ & $\begin{array}{c}0.4814 \\
(0.0168) \\
\end{array}$ \\
\hline Cyprus & $\begin{array}{c}0.5418 \\
(0.0214)\end{array}$ & $\begin{array}{c}0.6422 \\
(0.0180)\end{array}$ & $\begin{array}{c}0.4516 \\
(0.0232)\end{array}$ \\
\hline Germany & $\begin{array}{c}0.5587 \\
(0.0104) \\
\end{array}$ & $\begin{array}{c}0.5473 \\
(0.0110) \\
\end{array}$ & $\begin{array}{c}0.5031 \\
(0.0109)\end{array}$ \\
\hline Estonia & $\begin{array}{c}0.4551 \\
(0.0153)\end{array}$ & $\begin{array}{c}0.6838 \\
(0.0117)\end{array}$ & $\begin{array}{c}0.4040 \\
(0.0166)\end{array}$ \\
\hline Finland & $\begin{array}{l}0.5066 \\
(0.0077)\end{array}$ & $\begin{array}{c}0.7451 \\
(0.0049)\end{array}$ & $\begin{array}{c}0.4241 \\
(0.0082)\end{array}$ \\
\hline France & $\begin{array}{c}0.7001 \\
(0.0051)\end{array}$ & $\begin{array}{c}0.6400 \\
(0.0058)\end{array}$ & $\begin{array}{c}0.5022 \\
(0.0069)\end{array}$ \\
\hline Greece & $\begin{array}{c}0.4243 \\
(0.0157) \\
\end{array}$ & $\begin{array}{c}0.7013 \\
(0.0101) \\
\end{array}$ & $\begin{array}{c}0.4254 \\
(0.0158) \\
\end{array}$ \\
\hline Croatia & $\begin{array}{c}0.2811 \\
(0.0271) \\
\end{array}$ & $\begin{array}{c}0.6533 \\
(0,0193) \\
\end{array}$ & $\begin{array}{c}0.4130 \\
(0.0237) \\
\end{array}$ \\
\hline Hungary & $\begin{array}{c}0.4073 \\
(0.0112)\end{array}$ & $\begin{array}{c}0.6542 \\
(0.0084)\end{array}$ & $\begin{array}{c}0.5029 \\
(0.0103)\end{array}$ \\
\hline Ireland & $\begin{array}{c}0.4392 \\
(0.0118)\end{array}$ & $\begin{array}{c}0.5794 \\
(0.0105)\end{array}$ & $\begin{array}{c}0.3068 \\
(0.0137)\end{array}$ \\
\hline Italy & $\begin{array}{c}0.5426 \\
(0.0088)\end{array}$ & $\begin{array}{c}0.6710 \\
(0,0074)\end{array}$ & $\begin{array}{c}0.4414 \\
(0.0096)\end{array}$ \\
\hline Lithuania & $\begin{array}{c}0.2963 \\
(0.0022) \\
\end{array}$ & $\begin{array}{c}0.5720 \\
(0.0184)\end{array}$ & $\begin{array}{c}0.3774 \\
(0.0226) \\
\end{array}$ \\
\hline Luxembourg & $\begin{array}{c}0.5671 \\
(0.0176) \\
\end{array}$ & $\begin{array}{c}0.5618 \\
(0.0187) \\
\end{array}$ & $\begin{array}{c}0.4758 \\
(0.0203) \\
\end{array}$ \\
\hline Latvia & $\begin{array}{c}0.5031 \\
(0.0232) \\
\end{array}$ & $\begin{array}{r}0.7735 \\
(0.0114) \\
\end{array}$ & $\begin{array}{r}0.4399 \\
(0.0245) \\
\end{array}$ \\
\hline Malta & $\begin{array}{c}0.3425 \\
(0.0264)\end{array}$ & $\begin{array}{c}0.3875 \\
(0.0287)\end{array}$ & $\begin{array}{c}0.1950 \\
(0.0297)\end{array}$ \\
\hline Netherlands & $\begin{array}{c}0.3920 \\
(0,0174) \\
\end{array}$ & $\begin{array}{c}0.2251 \\
(0,0199)\end{array}$ & $\begin{array}{c}0.2426 \\
(0.0186)\end{array}$ \\
\hline Poland & $\begin{array}{c}0.4458 \\
(0,0108) \\
\end{array}$ & $\begin{array}{c}0.7401 \\
(0,0071) \\
\end{array}$ & $\begin{array}{c}0.4265 \\
(0.0109) \\
\end{array}$ \\
\hline Portugal & $\begin{array}{c}0.5162 \\
(0,0102) \\
\end{array}$ & $\begin{array}{c}0.7371 \\
(0,0072) \\
\end{array}$ & $\begin{array}{c}0.4869 \\
(0.0104) \\
\end{array}$ \\
\hline Slovenia & $\begin{array}{c}0.3377 \\
(0,0205)\end{array}$ & $\begin{array}{c}0.6021 \\
(0,0162)\end{array}$ & $\begin{array}{c}0.3504 \\
(0.0206)\end{array}$ \\
\hline Slovakia & $\begin{array}{c}0.4903 \\
(0.0168)\end{array}$ & $\begin{array}{c}0.7518 \\
(0,0109)\end{array}$ & $\begin{array}{c}0.4589 \\
(0.0185)\end{array}$ \\
\hline
\end{tabular}

Source: own calculation using HFCS data 
Spearman's correlation between the position of the household in the income distribution and the position of the household in the wealth distribution varies between 0.2811 in Croatia and 0.7001 in France. France is a clear outlier. The value of Spearman's rank correlation coefficient in France is significantly higher than in all other countries. Therefore the level of the correlation can be assessed as very high. Correlation between the distribution of income and distribution and wealth is high in Germany (significantly higher than in 13 other countries), Luxembourg and Italy (12 countries), Austria, Cyprus, Portugal, and Finland (11 countries). The correlation between both distributions is low in Malta (significantly lower than in 14 countries), Netherlands (13 countries), and Hungary (11 countries). The correlation between income and wealth is very low in Croatia (significantly lower than in 17 other countries), Lithuania (17 countries), and Slovenia (16 countries). It shall be noted that all countries with the very low correlation level are post-communist economies. It is possible that the privatization of housing assets, which was a popular policy solution implemented in Central and Eastern European Economies after 1989 lowered the correlation between household wealth and household income. The analysis presented in the next section proves that homeownership is negatively correlated with the strength of the link between the distribution of income and the distribution of wealth.

The correlation between the position of the household in the income distribution and the position of the household in the income distribution varies between 0.2251 in Netherlands and 0.7735 in Latvia. The correlation between the position of the household in both distributions is very high in Latvia, Finland, Slovakia, and Poland. In all four cases in a given country, it is statistically higher than in 16 other countries. The correlation between income and consumption is high in Greece, where it is significantly higher than in 12 other countries. The correlation is very low in Malta and the Netherlands. The Netherlands is a clear outlier, while in Malta correlation coefficient is significantly lower than in all countries except the Netherlands.

The correlation between the position of the household in the wealth distribution and the position of the household in the consumption distribution varies between 0.1950 in Malta and 0.5039 in Germany. The strength of the correlation in the top half of countries is similar, so we can not identify any country with a very high level of correlation. The correlation is high in Germany and France (significantly higher than in 13 other countries) and Hungary as well as Portugal (significantly higher than in 8 other countries). The correlation between wealth and consumption is very low in Malta and the Netherlands (significantly lower than in 19 other countries) and Ireland (significantly lower than in 16 other countries).

Table 3 presents the value of the multidimensional inequality index formulated by Araar (2009) and Gini indices calculated for all distributions. As described in the previous section we calculated the value of the index assuming an equal weight of all dimensions. The multidimensional inequality index varies between 0.3403 in Slovakia and 0.4503 in the Netherlands. It shall be noted that the cross-country variation of the multidimensional inequality index among countries is smaller than the cross-country variation of unidimensional Gini indices.

Cross-country differences in the value of the multidimensional inequality index are rather mild. In the strong majority of cross-country comparisons, the difference between considered countries is statistically insignificant. According to our criteria, multidimensional inequality may be assessed as high in Germany and Netherlands (in both cases in a given country it is significantly higher than in 15 other countries), Latvia (12 countries), and Estonia (11 countries). Multidimensional inequality is low in Slovakia (significantly lower than in 15 countries) and Greece (13 countries). In none of the countries, multidimensional inequality may be assessed as very high or very low. 
Table 3. Multidimensional and unidimensional inequality

\begin{tabular}{|c|c|c|c|c|}
\hline Country & $\begin{array}{l}\text { Multidimensional } \\
\text { Inequality Index }\end{array}$ & Gini Index Income & Gini Index Wealth & $\begin{array}{c}\text { Gini Index } \\
\text { Consumption }\end{array}$ \\
\hline Austria & $\begin{array}{c}0.3995 \\
(0.0115)\end{array}$ & $\begin{array}{c}0.3639 \\
(0.1545)\end{array}$ & $\begin{array}{c}0.7226 \\
(0.0172)\end{array}$ & $\begin{array}{c}0.2587 \\
(0.0043)\end{array}$ \\
\hline Belgium & $\begin{array}{c}0.3781 \\
(0.0088)\end{array}$ & $\begin{array}{c}0.3922 \\
(0.0089)\end{array}$ & $\begin{array}{c}0.6298 \\
(0.0191)\end{array}$ & $\begin{array}{c}0.2971 \\
(0.0067)\end{array}$ \\
\hline Cyprus & $\begin{array}{c}0.4161 \\
(0.0108)\end{array}$ & $\begin{array}{c}0.4227 \\
(0.0117)\end{array}$ & $\begin{array}{c}0.7290 \\
(0.0178)\end{array}$ & $\begin{array}{c}0.2792 \\
(0.0076)\end{array}$ \\
\hline Germany & $\begin{array}{c}0.4402 \\
(0.0055)\end{array}$ & $\begin{array}{c}0.4309 \\
(0.0077)\end{array}$ & $\begin{array}{c}0.7334 \\
(0.0090)\end{array}$ & $\begin{array}{c}0.3306 \\
(0.0044)\end{array}$ \\
\hline Estonia & $\begin{array}{c}0.4299 \\
(0.0083)\end{array}$ & $\begin{array}{c}0.4710 \\
(0.0065)\end{array}$ & $\begin{array}{c}0.7051 \\
(0.0188)\end{array}$ & $\begin{array}{c}0.3008 \\
(0.0048)\end{array}$ \\
\hline Finland & $\begin{array}{c}0.4086 \\
(0.0037)\end{array}$ & $\begin{array}{c}0.3896 \\
(0.0035)\end{array}$ & $\begin{array}{c}0.6617 \\
(0.0062)\end{array}$ & $\begin{array}{c}0.3588 \\
(0.0031)\end{array}$ \\
\hline France & $\begin{array}{c}0.4000 \\
(0.0034)\end{array}$ & $\begin{array}{c}0.3723 \\
(0.0053)\end{array}$ & $\begin{array}{c}0.6733 \\
(0.0059)\end{array}$ & $\begin{array}{c}0.3253 \\
(0.0036)\end{array}$ \\
\hline Greece & $\begin{array}{c}0.3605 \\
(0.0056)\end{array}$ & $\begin{array}{c}0.3530 \\
(0.0061)\end{array}$ & $\begin{array}{l}0.5948 \\
(0.0113\end{array}$ & $\begin{array}{c}0.3146 \\
(0.0058)\end{array}$ \\
\hline Croatia & $\begin{array}{c}0.3920 \\
(0.0137)\end{array}$ & $\begin{array}{c}0.5074 \\
(0,0125)\end{array}$ & $\begin{array}{c}0.6011 \\
(0.0272)\end{array}$ & $\begin{array}{c}0.3409 \\
(0.0254)\end{array}$ \\
\hline Hungary & $\begin{array}{c}0.4006 \\
(0.0063)\end{array}$ & $\begin{array}{c}0.4430 \\
(0.0066)\end{array}$ & $\begin{array}{c}0.6482 \\
(0.0117)\end{array}$ & $\begin{array}{c}0.2937 \\
(0.0043)\end{array}$ \\
\hline Ireland & $\begin{array}{c}0.3943 \\
(0.0069)\end{array}$ & $\begin{array}{c}0.4376 \\
(0.0091)\end{array}$ & $\begin{array}{c}0.6618 \\
(0.0114)\end{array}$ & $\begin{array}{c}0.3076 \\
(0.0058)\end{array}$ \\
\hline Italy & $\begin{array}{c}0.3965 \\
(0.0053)\end{array}$ & $\begin{array}{c}0.4266 \\
(0,0061)\end{array}$ & $\begin{array}{c}0.6063 \\
(0.0078)\end{array}$ & $\begin{array}{c}0.3334 \\
(0.0048)\end{array}$ \\
\hline Lithuania & $\begin{array}{r}0.3843 \\
(0.0076) \\
\end{array}$ & $\begin{array}{c}0.5119 \\
(0.0107) \\
\end{array}$ & $\begin{array}{r}0.5700 \\
(0.0141) \\
\end{array}$ & $\begin{array}{c}0.3302 \\
(0.0086) \\
\end{array}$ \\
\hline Luxembourg & $\begin{array}{c}0.3939 \\
(0.0116)\end{array}$ & $\begin{array}{c}0.4004 \\
(0.0096)\end{array}$ & $\begin{array}{c}0.6452 \\
(0.0267)\end{array}$ & $\begin{array}{c}0.3305 \\
(0.0115)\end{array}$ \\
\hline Latvia & $\begin{array}{c}0.4410 \\
(0.0115)\end{array}$ & $\begin{array}{c}0.4636 \\
(0.0133)\end{array}$ & $\begin{array}{c}0.6784 \\
(0.0180)\end{array}$ & $\begin{array}{c}0.3320 \\
(0.0138)\end{array}$ \\
\hline Malta & $\begin{array}{c}0.3587 \\
(0,0167)\end{array}$ & $\begin{array}{c}0.4069 \\
(0.0184)\end{array}$ & $\begin{array}{c}0.6002 \\
(0.0267)\end{array}$ & $\begin{array}{c}0.3616 \\
(0.0195)\end{array}$ \\
\hline Netherlands & $\begin{array}{c}0.4523 \\
(0,0089)\end{array}$ & $\begin{array}{c}0.4031 \\
(0,0094)\end{array}$ & $\begin{array}{c}0.7533 \\
(0.0147)\end{array}$ & $\begin{array}{c}0.5174 \\
(0.0126)\end{array}$ \\
\hline Poland & $\begin{array}{c}0.3602 \\
(0,0095)\end{array}$ & $\begin{array}{c}0.3793 \\
(0,0074)\end{array}$ & $\begin{array}{c}0.5623 \\
(0.0164)\end{array}$ & $\begin{array}{c}0.3154 \\
(0.0078)\end{array}$ \\
\hline Portugal & $\begin{array}{c}0.4232 \\
(0,0066)\end{array}$ & $\begin{array}{c}0.4533 \\
(0,0081)\end{array}$ & $\begin{array}{c}0.6759 \\
(0.0130)\end{array}$ & $\begin{array}{c}0.3149 \\
(0.0045)\end{array}$ \\
\hline Slovenia & $\begin{array}{c}0.3842 \\
(0,0085)\end{array}$ & $\begin{array}{c}0.4811 \\
(0,0097)\end{array}$ & $\begin{array}{c}0.5798 \\
(0.0168)\end{array}$ & $\begin{array}{c}0.3316 \\
(0.0065)\end{array}$ \\
\hline Slovakia & $\begin{array}{c}0.3403 \\
(0.0115)\end{array}$ & $\begin{array}{c}0.3901 \\
(0.0219)\end{array}$ & $\begin{array}{c}0.5333 \\
(0.0150)\end{array}$ & $\begin{array}{c}0.2568 \\
(0.0058)\end{array}$ \\
\hline
\end{tabular}

Source: own calculation using HFCS data

Multidimensional analysis of inequality changes the picture emerging from the unidimensional inequality analysis. For example, the level of wealth inequality in Austria is among the highest in Europe, but thanks to low levels of income and consumption inequality multidimensional inequality is not high. Although income inequality is highest in Lithuania, multidimensional inequality in Lithuania is on moderate level. Income inequality is also very high in Greece, but multidimensional inequality in this country is low. France is also an interesting example. Despite a high correlation between the position of the household in each of the dimensions, the level of multidimensional inequality is similar to other countries. 
Table 4 presents the contribution of each dimension to the value of the multidimensional inequality index. In all countries contribution of wealth inequality is the biggest, the contribution of income inequality is second and the contribution of consumption inequality is smallest. The contribution of wealth inequality varies between $49.02 \%$ in Lithuania and $60.06 \%$ in Austria. In all countries except Lithuania and Slovakia contribution of wealth inequality is higher than $50 \%$. The contribution of income inequality varies between $24.48 \%$ in Austria and $30.77 \%$ in Lithuania. The contribution of the consumption inequality varies between $15.46 \%$ in Austria to $22.29 \%$ in the Netherlands.

Table 4. Contribution of each dimension to multidimensional inequality

\begin{tabular}{lccc}
\hline \multicolumn{1}{c}{ Country } & Wealth inequality & Contribution of & \\
\hline Austria & 0.6006 & 0.2448 & 0.1546 \\
\hline Belgium & 0.5534 & 0.2612 & 0.1854 \\
\hline Cyprus & 0.5836 & 0.2601 & 0.1563 \\
\hline Germany & 0.5526 & 0.2693 & 0.1781 \\
\hline Estonia & 0.5424 & 0.2893 & 0.1683 \\
\hline Finland & 0.5353 & 0.2538 & 0.2109 \\
\hline France & 0.5592 & 0.2509 & 0.1899 \\
\hline Greece & 0.5449 & 0.2463 & 0.2088 \\
\hline Croatia & 0.5071 & 0.2930 & 0.1999 \\
\hline Hungary & 0.5343 & 0.2819 & 0.1838 \\
\hline Ireland & 0.5568 & 0.2801 & 0.1631 \\
\hline Italy & 0.5075 & 0.2913 & 0.2012 \\
\hline Lithuania & 0.4902 & 0.3077 & 0.2021 \\
\hline Luxembourg & 0.5459 & 0.2614 & 0.1927 \\
\hline Latvia & 0.5036 & 0.2965 & 0.1999 \\
\hline Malta & 0.5571 & 0.2568 & 0.1861 \\
\hline Netherlands & 0.5503 & 0.2268 & 0.2229 \\
\hline Poland & 0.5171 & 0.2665 & 0.2164 \\
\hline Portugal & 0.5299 & 0.2860 & 0.1841 \\
\hline Slovenia & 0.4990 & 0.3045 & 0.1964 \\
\hline Slovakia & 0.5183 & 0.3024 & 0.1794
\end{tabular}

Source: own calculation using HFCS data

\section{Determinants of the strength of the correlation between distributions}

Cross-country differences in the value of the Multidimensional Inequality Index are a consequence of different levels of unidimensional inequalities and different correlations between them in different countries. The discussion of determinants of unidimensional inequalities is out of the scope of this paper. Significant literature on this issue already exists (e.g. Furceri \& Ostry, 2019; Brzeziński \& Sałach, 2020; Hussey et al., 2021) As described above cross-country differences in the value of the Multidimensional Inequality Index are rather mild and often not statistically significant. On the other hand, however, we identify a lot of variation in the strength of the link between distributions of income, wealth, and consumption in analyzed countries.

What determines the strength of the correlation among the position of the household in income, wealth, and consumption distribution? This question deserves a separate research paper. In this section, we only present information on the correlation between the value of Spearman's rank correlation coefficient and various socioeconomic variables. We treat each country as a separate observation unit. Among explanatory factors, we include the level of inequality of given distributions measured by the Gini index, the median value of given 
distributions, homeownership, the share of households headed by a person older than 65 years, the mean number of people in the household, and the degree of the oversampling of the top decile in a given country. Determinants of the correlation among considered distributions are presented in Table 5.

Table 5. Determinants of the correlation among distributions

\begin{tabular}{lccc}
\hline \multicolumn{1}{c}{ Variable } & \multicolumn{3}{c}{ Correlation between } \\
\hline median wealth & 0.2659 & & Income and Consumption \\
\hline median income & $0.4662^{* *}$ & $-0.4070^{*}$ & -0.0482 \\
\hline median cons. &. & 0.0035 & -0.0310 \\
\hline wealth ineq. & $0.4212^{*}$ &. & 0.0054 \\
\hline income ineq. & $-0.5501^{* * *}$ & 0.0077 & 0.1683 \\
\hline cons ineq. &. & $-0.7256^{* * *}$ & $-0.5759^{*}$ \\
\hline homeownership & $-0.6345^{* *}$ & 0.2129 & -0.1172 \\
\hline no.. people & -0.2352 & 0.2272 & -0.0779 \\
\hline$\%$ older than 65 & -0.1305 & -0.2425 & -0.1584 \\
\hline oversampling & $0.5544^{*}$ & 0.0035 & $0.4203^{*}$ \\
\hline
\end{tabular}

Note: asterisks denote statistical significance of the correlation, $* p<0.1 ; * * p<0.05 ; * * * p<0.01$.

Source: own calculation using HFCS data

According to our results, the median income is positively correlated with the strength of the correlation between the position of the household in the income distribution and the position of the household in the wealth distribution. This result may be driven by low median incomes in CEE countries, where the correlation between income and wealth is rather low. The median income is also negatively correlated with the strength of the correlation between the position of the household in the income distribution and the position of the household in the consumption distribution. If the median income in a given country is higher the correlation between wealth and income is stronger and the correlation between income and consumption is lower. While wealth inequality is positively correlated with the correlation between income and wealth, income inequality is negatively correlated with the correlation between income and wealth. Consumption inequality is negatively correlated with the correlation between income and consumption as well as the correlation between wealth and consumption.

Homeownership is negatively correlated with the correlation between income and wealth. In countries, where homeownership is high the link between income and wealth is weaker. This result is not surprising. Homeownership is widely seen as an important determinant of wealth inequality (Causa et al., 2019; Brzeziński \& Sałach, 2020). If households own their main residence their wealth is significantly higher. CEE countries are among those with the highest share of households owning their main residence. Because many households received ownership rights in housing privatization after the economic transition (Yemtsow, 2007) the impact of income on the probability of owning the main residence as well as the correlation between income and the value of the household main residence is limited.

As described in the second section countries participating in the HFCS choose their oversampling strategy. Therefore the degree of the oversampling of the top decile varies among countries. The degree of the oversampling of the top decile is positively correlated with the correlation between income and wealth as well as the correlation between wealth and consumption. However, this correlation is only marginally statistically significant. This result indicates that the results presented in this paper may be partially driven by cross-country differences in the method of oversampling wealthy households. A low level of statistical 
significance and the fact that the Gini index is less vulnerable to changes in the top of the distribution limits the role of this constraint.

\section{Conclusion}

Unidimensional analysis of inequality provides valuable, but limited information on the scope of socio-economic inequality. Therefore the literature on multidimensional inequality is growing fast. Because of limited data availability, multidimensional inequality is usually investigated in the single-country setting.

We use a novel high-quality dataset to measure the multidimensional inequality of income, wealth, and consumption as well as the correlation between the position of the household in their distribution in 21 European countries. We use the bootstrap method to analyze the statistical significance of cross-country differences in the value of the Multidimensional Inequality Index and the correlation coefficients.

We find that the correlation between the position of the household in considered distributions varies significantly across countries. However, cross-country differences in the scope of the multidimensional inequality are rather mild. In the strong majority of cases of cross-country differences are not statistically significant. Wealth inequality is a crucial contributor to multidimensional inequality. Multidimensional analysis of inequality changes the picture emerging from the unidimensional inequality analysis. Many countries with high leveles of inequality in one of the dimensions have moderate levels of multidimensional inequality.

Because of high cross-country variation in the strength of the link between distributions we analyze the link between the value of Spearman's rank correlation coefficient and socio-economic factors. According to our findings higher level of homeownership strongly decreases the correlation between income and wealth. In countries with higher levels of wealth inequality, the correlation between income and wealth is stronger. On the other hand, if income inequality is higher the link between both distributions is weaker. Higher consumption inequality weakens the link between income and consumption as well as the link between wealth and consumption.

The main limitation of our research is the data structure. As described in the paper joined data on household income, wealth and consumption are scarce. In our view the Household Finance and Consumption Survey provides good data on all dimensions, but data on income and consumption are formulated in a way, which is less than perfect Because net income is not available we have to use gross income as a measure of household income. Our measure of consumption is probably too narrow. It would be beneficial to replicate our work using data on net incomes and broader consumption definitions. As far as we know such a dataset is unavailable. Moreover, we think that the impact of household structure on multidimensional inequality and the link between distribution should be further investigated. Finally, it would be great to find another data source and extend our research to cover a higher number of countries. However, as far we know such a dataset is not currently available. 


\section{References}

Aaberge, R., \& Brandolini, A. (2015). Multidimensional Poverty and Inequality. In A.B Atkinson \& Bourguignon, F. (Eds), Handbook of Income Distribution (vol. 2, 141-216). Oxford: North-Holland.

Araar, A. (2009). On the Decomposition of the Gini Coefficient: An Exact Approach, with an Illustration Using Cameroonian Data. Cahier de recherche/Working Paper 06-02, CIRPEE. Laval: Université Laval.

Araar, A. (2009). The Hybrid Multidimensional Index of Inequality. Cahier de recherche/Working Paper 09-45. CIRPEE. Laval: Université Laval.

Atkinson, A.B., \& Bourguignon, F. (1982). The Comparison of Multi-Dimensioned Distributions of Economic Status. Review of Economic Studies, 49(2), 183-201.

Banerjee, A.K. (2010). A multidimensional Gini index. Mathematical Social Sciences, 60(2), 87-93.

Biewen, M. (2002). Bootstrap inference for inequality, mobility and poverty measurement. Journal of Econometrics, 108(2), 317-342.

Bosmans, K., Decancq, K., \& Ooghe, E. (2015). What do normative indices of multidimensional inequality really measure?. Journal of Public Economics, 130, 94104.

Brandolini, A. (2009). On applying synthetic indices of multidimensional well-being: health and income inequalities in France, Germany, Italy, and the United Kingdom. In R. Gotoh. \& Dumouchel, P. (Eds), Against Injustice. The New Economics of Amartya Sen. Cambridge: Cambridge University Press.

Brzeziński, M. \& Sałach, K. (2020). Why wealth inequality differs between post-socialist countries?. Working Paper 2020-551, ECINEQ.

Brzeziński M., Sałach K. \& Wroński M. (2020). Wealth inequality in Central and Eastern Europe: evidence from joined household survey and rich lists' data. Economics of Transition and Institutional Change, 28(4), 637-660.

Bui, T.K.T., \& Erreygers G. (2020). Multidimensional Inequality in Vietnam, 2002-2012. Economies, 8, 29.

Causa, O., Woloszko, N., \& Leite, D. (2019). Housing, wealth accumulation and wealth distribution: evidence and stylized facts. Economics Department Working Papers No. 1588. Paris: OECD.

Chernick, M.R. (2008). Bootstrap Methods: A Guide for Practitioners and Researchers. Wiley Series in Probability and Statistics. Hoboken, NJ: John Wiley\&Sons.

Clementi, F., \& Gianmoena, L. (2017). Modeling the Joint Distribution of Income and Consumption in Italy. A Copula-Based Approach With $\kappa$-Generalized Margins. In M.Gallegati, A.Palestrini, \& Russo, A. (Eds), Introduction to Agent-Based Economics (191-228). London: Academic Press.

Cowell, F. (2011). Measuring Inequality.LSE Perspectives in Economic Analysis. Oxford: Oxford University Press.

Decancq, K., \& Lugo, M.A. (2012). Inequality of Wellbeing: A Multidimensional Approach. Economica, 79 (316), 721-746.

Decancq, K. (2017). Measuring Multidimensional Inequality in the OECD Member Countries with a Distribution-Sensitive BetterLife Index. Social Indicators Research, 131(3), 1057-1086.

Fisher, J., Johnson, D., Smeeding, T., \& Thompson, J. (2018). Inequality in 3-D: Income, Consumption, and Wealth. Finance and Economics Discussion Series 2018-001. Washington D.C.: Board of Governors of the Federal Reserve System. 
Fluckiger, Y. \& Silber, J. (1994). The Gini Index and the Measurement of Multidimensional Inequality. Oxford Bulletin of Economics and Statistics, 56(2), 225-228.

Furceri, D. \& Ostry, J.D. (2019). Robust determinants of income inequality. Oxford Review of Economic Policy, 35(3), 490-517.

Gajdos, T. \&Weymark, J.A. (2005). Multidimensional generalized Gini indices. Economic Theory, 26(3), 471-496.

Hirschman, D. (2016). Rediscovering the 1\%: Economic Expertise and Inequality Knowledge. SocArXiv Papers

Household Finance and Consumption Network (2020a). The Household Finance and Consumption Survey: Results from the 2017 wave. ECB Statistics Paper Series No. 36. Frankfurt am Main: European Central Bank.

Household Finance and Consumption Network (2020b). The Household Finance and Consumption Survey: Methodological report for the 2017 wave, ECB Statistics Paper Series No. 35, European Central Bank.

Household Finance and Consumption Network (2020b). The Household Finance and Consumption Survey. Wave 2017: Statistical Tables. Frankfurt am Main: European Central Bank.

Hussey, A.J., Jetter, M. \& McWilliam, D. (2021). The Fundamental Determinants of Economic Inequality in Average Income Across Countries: The Declining Role of Political Institutions. Review of Income and Wealth, 67(1), 104-33.

Jäntti M., Sierminska, E. \& Van Kerm, P. (2015). Modelling the Joint Distribution of Income and Wealth. IZA DP No. 9190. Bonn: IZA.

Jung, H-S., Kim, S-W. \& Ahn, S-H. (2014). Multidimensional Inequality in South Korea: An Empirical Analysis. Asian Social Work and Policy Review, 8(2), 170-191.

Justino, P., Litchfield, J. \& Nimi, Y. (2004). Multidimensional Inequality: An Empirical Application to Brazil. PRUS Working Paper No. 24, Poverty Research Unit at Sussex. Brighton: University of Sussex.

Kennickel, A. B. (2009). Ponds and Streams: Wealth and Income in the U.S., 1989 to 2007. Finance and Economic Discussion Series 2009-13. Washington D.C: Board of Governors, Federal Reserve.

Kennickel A. B. (2019). The tail that wags: differences in effective right tail coverage and estimates of wealth inequality. Journal of Economic Inequality, 17, 443-59.

Khan, A.U., Saboor, A. \& Shah, A. (2020). Dynamics of Multidimensional Inequality Across Different Occupations in Pakistan. Social Indicators Research, 153, 93-109.

Kolm, S.-C. (1977). Multidimensional Egalitarism. Quarterly Journal of Economics, 91(1), $1-13$.

Koshevoy, G.A. \& Mosler, K. (1997). Multivariate Gini Indices. Journal of Multivariate Analysis, 60(2), 252-276.

Lerman, R.I. \& Yitzhaki (1985). Income Inequality Effects by Income Source: A New Approach and Applications to the United States. Review of Economics and Statistics, 67(1), 151-156.

Lugo, M.A. (2007). Comparing Multidimensional Indices of Inequality: methods and application. In J. Bishop J. and Amiel, Y. (Eds.) Inequality and Poverty (Research on Economic Inequality, Vol. 14, 213 - 236). Bingley: Emerald Group Publishing Limited.

List, C. (1999). Multidimensional Inequality Measurement: A Proposal. Nuffield College Working Paper in Economics. Oxford: Nuffield College.

Maasoumi, E. (1986). The Measurement and Decomposition of Multi-Dimensional Inequality. Econometrica, 54(4), 991-997.

OECD (2013). OECD Guidelines for Micro Statistics on Household Wealth. Paris: OECD Publishing. 
OECD (2020). How's Life? 2020: Measuring Well-being. Paris: OECD Publishing.

Office for National Statistics (2020). Household income, spending and wealth, Great Britain: April 2016 to March 2018. Examining income, spending, and wealth to better understand the financial well-being of households. London: Office for National Statistics.

Parente, F. (2019). A Multidimensional Analysis of the EU Regional Inequalities. Social Indicators Research 143(3), 1017-1044.

Piketty, T. (2014). Capital in the Twenty-First Century. Cambridge: Harvard University Press.

Permanyer, I. (2010). The Measurement of Multidimensional Gender Inequality: Continuing the Debate. Social Indicators Research, 95(2), 181-198.

Reid-Henry, S. (2015). The Political Origins of Inequality. Why A More Equal World Is Better For Us All. Chicago: Chicago University Press.

Rohde, N. \& Guest, R. (2012). Multidimensional Racial Inequality in the United States. Social Indicators Research, 114(2), 591-605.

Rubin, D.,B. (1987). Multiple Imputation for Nonresponse in Surveys. Wiley series in probability and mathematical statistics. Applied probability and statistics. New York: John Wiley \& Sons.

Ruiz, N. (2015). Measuring The Joint Distribution of Household's Income, Consumption and Wealth Using Nested Generalized Mean. Singapore Economic Review, 63(3), 759-785.

Sen, A. (1997). From income inequality to economic inequality. Southern Economic Journal, 64, 384-401.

Sosa Escudero, W. \& Gasparini, L. (2000). A note on the statistical significance of changes in inequality. Económica, 46(1), 111-122.

Stiglitz, J. E., Sen, A. \& Fitoussi, J-P. (2009). Report by the Commission on the Measurement of Economic Performance and Social Progress. Commission on the Measurement of Economic Performance and Social Progress.

Steiner, V. \& Zhu, J. (2021). A Joint Top Income and Wealth Distribution.Discussion Paper 2021/3, School of Business \& Economics. Berlin: Freie Universität Berlin.

Tsui, K.Y. (1995). Multidimensional Generalizations of the Relative and Absolute Inequality Indices: The Atkinson-Kolm-Sen Approach. Journal of Economic Theory, 67(1), 251265.

Tsui, K.Y. (1999). Multidimensional Inequality and Multidimensional Generalized Entropy Measures: An Axiomatic Derivation. Social Choice and Welfare, 16, 145-57.

Van Phan, P. \& O'Brien, M. (2019). Multidimensional wellbeing inequality in a developing country: A case study of Vietnam. Social Indicators Research, 1/2019.

Wroński, M. (2019). Kluczowe problemy metodologiczne w badaniach nad majątkiem gospodarstw domowych (Key Methodological Issues in the Research on Household Wealth), Wiadomości Statystyczne (Polish Statistician), 5(696), 34-47.

Yemtsov, R. (2007). Housing Privatization and Household Wealth in Transition. Research Paper No. 2007/02. Helsinki: UNU-WIDER. 